\title{
Universiteit
}

Leiden

The Netherlands

\section{The nominal cleft construction in Coptic Egyptian}

Reintges, C.H.; Lipták, A.K.; Cheng, L.L.; Kiss, K.É.

\section{Citation}

Reintges, C. H., Lipták, A. K., \& Cheng, L. L. (2005). The nominal cleft construction in Coptic Egyptian. In K. É. Kiss (Ed.), Studies in Generative Grammar (pp. 105-136). Berlin: De Gruyter Mouton. doi:10.1515/9783110902228.105

Version: $\quad$ Publisher's Version

License: $\quad$ Licensed under Article 25fa Copyright Act/Law (Amendment Taverne)

Downloaded from: https://hdl.handle.net/1887/62798

Note: To cite this publication please use the final published version (if applicable). 


\title{
The nominal cleft construction in Coptic Egyptian
}

\author{
Chris H. Reintges, Anikó Lipták and \\ Lisa Lai Shen Cheng
}

\section{Introduction}

Cleft sentences belong to a larger family of focusing constructions. In a language like English, clefts are formed by dividing a simple clause into two parts, namely an initial focus (the cleft constituent) and a backgrounded proposition, which is expressed by a relative clause (see Huddleston \& Pullum 2002: 1414-20; Lambrecht 2001).

\section{(1) English it-clefts}

a. It was a red wool sweater that I bought.

b. It was the wording of the question that confused me.

This paper examines the corresponding construction in Coptic Egyptian, which represents the latest developmental stage of the Ancient Egyptian language. The modern term Coptic is derived from Middle Arabic qubti itself a corruption of the Greek word (ai)gypt(ios) 'Egyptian'. At the roots of the literary production lies the translation of the Greek Bible into Coptic Egyptian. The earliest Biblical manuscripts date from about $350 \mathrm{CE}$, but go back to the third century. Coptic Egyptian continued to be in use well beyond its extinction as a spoken language. ${ }^{1}$

Coptic is actually a dialect cluster, consisting of at least six regional varieties, two of which gained supra-regional importance: Sahidic, the language of the whole Nile valley above the Delta, and Bohairic, the language of the Nile Delta. Prior to the Arabic conquest in $641 \mathrm{CE}$, Sahidic was the predominant literary dialect of Coptic. Its supremacy became challenged by Bohairic Coptic from the $9^{\text {th }}$ century onwards. By the $11^{\text {th }}$ century, Bohairic had replaced Sahidic as the official church language and become the sole representative of Coptic Egyptian, which survived as the liturgical language of the present-day Coptic Orthodox Church. The language material of this paper is exclusively drawn from Sahidic Coptic, the main reference dialect. ${ }^{2}$ 
Turning to the topic of our paper, cleft sentences are very common in the syntactic patterns of Sahidic Coptic to indicate the focal status of a nominal argument. As with English clefts, Coptic cleft constructions have a biclausal syntax, yet express a single proposition. The focused DP $p$-tfoeis 'the Lord' in (2a), the wh-subject nim 'who' in (2b), as well as the contrastively stressed pronoun ntof 'HE' in ( $2 \mathrm{c})$ are all associated with an out-offocus relative clause that is introduced by the relative complementiser et 'that'. (Relative gaps are indicated as '

a. DP-clefts

p-t foeis gar $p(e) \quad[\mathrm{cP}$ et $\quad$ o m-metre

DEF:SM-lord PCL PRON:SM $C_{\text {REL }}$ (PRES) be as-witness n-ta-senedis ].

to-DEF:SM:1S-conscience

'For (it is) the Lord who is witness to my conscience.'

(V. Pach. 89: 1-2)

b. Wh-clefts

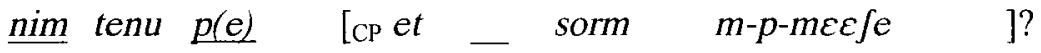
who ADV PRON:SM $C_{\text {REL }}$ (PRES) misguide DO-DEF:SM-crowd

'Who (is it) now that is misleading the crowd?'

(Acts of Andrew and Paul 212:231)

c. Pronoun clefts

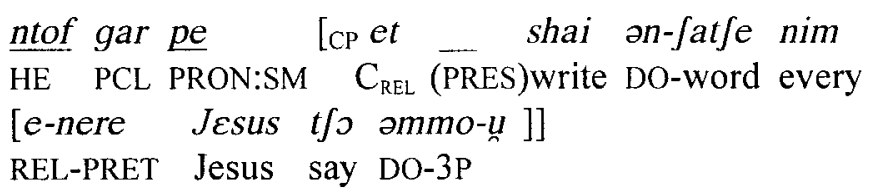

'Since (it is) him who wrote down every word that Jesus had said.'

(Pistis Sophia 71: 5-6)

Different from English it-clefts, there is no copular verb in the Coptic counterpart that connects the cleft constituent to the subordinate relative clause. Instead, a deictic pronoun (glossed as PRON) is employed to perform this linkage function. The deictic pronoun recurs in predicational and identificational nominal sentences, as shown by the contrast between ( $3 a$ ) and ( $3 b$ ) below. ${ }^{4}$ 
a. Nominal clefts [DP PRON CP]

anok gar $\frac{p(e)}{e} \quad[e t \quad$ nuhom ommo-ton $e \beta o l$
I PCL PRON:SM $\mathrm{C}_{\mathrm{REL}}$ (PRES) save DO-2P PCL
hon thlipsis nim ]
from trial every
'For (it is) me who saves you from every trial.'

(Eudoxia 50: 22-23)

b. Identificational nominal sentences (equatives) [DP PRON DP]

$$
\begin{aligned}
& \text { anok pe p-fere } m \text {-p-nute } \\
& \text { I PRON:SM DEF:SM-son of-DEF:SM-god } \\
& \text { 'I (am) the son of God.' }
\end{aligned}
$$

(Abbatôn 240: 13)

The nominal cleft construction has received a considerable amount of attention in Coptic language studies. As already established in Polotsky (1962), nominal clefts are not pseudo-clefts in which a free (headless) relative clause functions as the primary predicate of the entire construction. As of yet, the structural analogy between cleft and nominal predicational sentences as well as the different semantic types of focus that are expressed through clefting have not received a principled explanation. By making use of the analytical tools made available by generative syntax, we can make the relationship between the constituents of nominal clefts, their structural position, and their meaning and function more precise and draw parallels with other constructions, in particular, nominal predicational sentences and relative constructions.

The aim of the present study is therefore two-fold: to clarify the descriptive facts and to develop a configurational analysis of Coptic cleft sentences that captures the relationship between sentence form and information structure in a straightforward way. The key idea is that clefts have an underlying small clause configuration headed by the deictic pronoun. As the subject of the small clause, the cleft constituent underlies strict categorial restrictions: it must be a nominal category (either a DP or an NP). As a focus phrase, it cannot remain in-situ within the small clause, but must move to a designated focus projection in the left periphery of the clause.

The analysis of Coptic nominal clefts pursued in this paper contributes to the ongoing research on the mapping between discourse properties and leftperipheral functional superstructure. The Coptic facts provide evidence for the existence of a type of clefting that involves A-bar movement. They also show that focus fronting of the cleft constituent correlates with contrastive focus interpretation, but may also express new information focus. 
The organization of this paper is as follows. Section 2 is concerned with the range of focus interpretations that the cleft constituent may assume. Section 3 provides an overview of the main syntactic properties of nominal cleft sentences, with particular attention for their biclausal structure and agreement facts. Section 4 presents a configurational analysis of Coptic clefts. We will argue that nominal clefts have an underlying small clause structure, upon which an articulated left periphery is erected. Cleft formation involves focus fronting of the clefted DP into the specifier position of a designated focus phrase. Section 5 summarizes the main results of the paper.

\section{Types of focus in nominal clefts}

Coptic cleft sentences are typically used for contrastive emphasis with various degrees of strength. Following Rooth (1992) and subsequent research, we assume that contrastive focus specifies a subset of the given set of discourse entities for which the backgrounded proposition holds true, but at the same time implies a set of alternatives for which that proposition does not hold true. The set of alternatives brought into play by contrastive focus may be overtly given, as in (4). The most natural interpretation of this example is one in which the contrast set on which focus operates consists of the clefted DP Augustos Kostantinos and the DP complement Diokletianos of the complex preposition e-p-ma 'instead' (lit. in the place of).

Contrasted discourse referents

\begin{tabular}{|c|c|c|c|c|}
\hline ugustos & $\underline{\text { Kostantinos }}$ & p-rto & n-dikaijos & pe \\
\hline Augu & Constantine & DEF:SM-king & of-righteous & PRON:SM \\
\hline & $p-t$ & pe.n- & & na-n $\quad$ n-rro \\
\hline & $\mathrm{DE}$ & DEF & & for-1 $\mathrm{P}$ as-king \\
\hline$e-p-m a$ & $m-p-a n$ & tomos & $n$-at- $\int i_{l}$ & Diokletianos \\
\hline $\begin{array}{l}\text { at-DEF:SM- } \\
p \text {-rro }\end{array}$ & $\begin{array}{l}\text { place of-DE } \\
m-p-t \int i-n\end{array}$ & :SM-crimin & & \\
\hline
\end{tabular}

DEF:SM-king of-DEF:SM-take-DO-injustice

'(It is) Augustus Constantine, the righteous king, who the Lord, Our God, has raised as a king for us instead of the shameless criminal Diocletian, the king of injustice.'

(Eudoxia 38: 1-3)

The strongest form of contrast is corrective or counter-assertive focus, used in contexts where the speaker contradicts a previous utterance. Counter- 
assertive focus is exemplified by pairs of negative and affirmative clefts, in which the contrasted foci specify different values for the same proposition, as shown in (5).

(5) Juxtaposition of negative and affirmative cleft

$m$ - $p$-rome an $p(e) \quad\left[{ }_{\mathrm{CP}}\right.$ et $\quad t / i k \beta a$

NEG DEF:SM-man NOT PRON:SM $C_{\text {REL }}$ (PRES) take vengeance

nhet-s hn $u-k^{y}$ ont ]

by-3SF in INDEF:SM-wrath

ntos ntof $p(e) \quad[\mathrm{cP} e t \quad k$ to $m$-p-rome

SHE ADV PRON:SM $C_{\text {REL }}$ (PRES) turn DO-DEF:SM-man

e-p-ma [CPeto-s-wof e-kons mmau ]]

at-DEF:SM-place REL-(PRES)-3SF-want to-wound there

'(It is) not the man who takes vengeance by it (the sword) wrathfully. Rather (it is) it (the sword) that turns the man to the place where it wants to wound.'

(Shenoute IV 12: 10-12)

In the following set of data, the contrastive focus reading is evident from the use of dedicated focus particles. The emphatic reflexives mawaa-n 'ourselves' in (6a) and ho 'myself' in (6b) below impose an exclusive interpretation on the cleft constituent. It is asserted that none of the alternatives could provide a value for the open predication contained in the restrictive relative clause.

(6) Modification of the clefted DP by emphatic reflexives

a. anon de mawaa-n $p(e) \quad[\mathrm{CP}$ et foop m-pei-ma ] WE PCL OWN-1P PRON:SM $C_{\text {REL }}$ (PRES) reside in-DEM:SM-place '(It is) only us who reside here.'

(Budge, Martyrd. 221:2-3)

b. $\underline{\text { anok }} \underline{h o} \quad$ pe $\quad[\mathrm{CP} n t-a-i-r \quad n o \beta e$ ero-k

I SELF-1S PRON:SM REL-PERF-1S-do sin against-2SM n-u-sop [n-wot ]

in-INDEF:S-time of-single

'(It is) me, however, who sinned against you just once!'

(Acts of Andrew and Paul 200: 87)

Consider next the cleft construction in (7), in which the long discourse topic DP $p$-nute $n t$-a-f-fope $m n$ 'God who has been with (DP)' functions as the antecedent of the clefted pronoun ntof 'he'. The interpretation of this 
example is clearly not contrastive, as can be seen from the presence of the additive focus particle on 'also, too'.

(7) Non-contrastive clefted pronoun

p-nute [CP $n t$-a-f-fope $m n \quad n$-genea [CP $n t-a-u$-fope DEF:SM-god REL-PERF-3SM-be with DEF:P-generation REL-PERF-3P-be e-a-u-weine et $\beta$ e te.u-mnt-akaireos

REL-PERF-3P-pass.by because of DEF:SF:3P-NOM-unharmed mn te.u-pistis e-p-nute ]]

with DEF:SF-faith towards-DEF:SM-god

$\underline{\text { ntof }}$ on $p(\mathrm{e}) \quad[\mathrm{CP}$ et na-Jope $m n$ n-genea

HE PCL PRON:SM $C_{\text {REL }}$ FUT-be with DEF:P-generation [CP et - neu ]]

$\mathrm{C}_{\text {REL }}$ (PRES) come

'God who has been with the generations that existed and passed by because of their unharmed state and their faith in God, (it is) him, too, who will be with the generations to come.'

(Testament of Isaac 228: 13-16)

As we can see from (8) below, no definiteness restriction is operative on the cleft constituent in Coptic Egyptian. ${ }^{5}$ The cleft sentence in (8a) occurs in the opening sequence of a new narrative unit. We may therefore plausibly assume that the indefinite DP $u$ - $h \supset \beta$ nte $p$-nute 'a divine matter' corresponds to presentational focus, which introduces a new topic into the discourse. In $(8 \mathrm{~b}-\mathrm{c})$, on the other hand, the indefinite NPs hen-kuwi 'a few (things)' and $u$-fcre 'a son' are modified by the scalar focus particle emate 'only' and the degree adjective wot 'single', respectively, and are both presentational and contrastive foci.

(8) Clefted indefinite DPs

a. $\underline{u-h o \beta}$ nte $p$-nute $p(e) \quad[\mathrm{CP}$ e-ti-fatfe nmme-tn INDEF:S of DEF:SM-god PRON:SM REL-(PRES)-1S-speak with-2P et $\beta \varepsilon \varepsilon t-f$ ] about-3SM '(It is) a divine matter that I am speaking to you about.'

(Eudoxia 60: 24-25) 
b. plen efte hen-kuwi emate n(e) [CP eto-n-na-tfoo-u ADV if INDEF:P-small PCL PRON:P REL-1 P-FUT-Say-3P hn ne.f-katorthoma ]

from DEF:P.3SM-achievement

'Yet even though (it is) only a few (things) that we are going to say about his achievements.'

(Zenobius 201: 13)

c. $\underline{u-\int \varepsilon r e} \underline{n-w o t} p(\mathrm{e}) \quad[\mathrm{cP}$ et - foop na-i]

INDEF:S-child of-single PRON:SM $C_{\text {REL }}$ (PRES) be for-1s

'(It is) a single son that I have.' (Acts of Andrew and Paul 194: 22)

In summary, Coptic nominal clefts are not a purely contrastive focus device, but allow for a much broader range of semantic focus interpretations (cf. Doetjes, Rebuschi \& Rialand 2004 for similar observation on the French c'est XP que/qui 'it/that is XP who' construction). ${ }^{6}$

\section{Syntactic properties of Coptic clefts}

This section reviews the main structural properties of Coptic nominal clefts. We will show that clefts minimally involve two clausal projections: the matrix clause is a nominal predicational sentence into which a relative clause is embedded: [CP1 DP PRON [CP2 RELATIVE CLAUSE]]. In this structure, the relative clause lacks nominal properties, i.e. it is not a free relative clause. We will also look at the categorial restriction on the cleft constituent and the agreement behaviour of the deictic pronoun.

\subsection{The nature of the relative clause}

In the literature on nominal cleft constructions, the categorial status of the relative clause has been an issue of major importance. For Coptic nominal clefts, it has been argued in the descriptive literature that the relative clause is not a free relative with nominal properties (e.g. Polotsky 1962; Layton 2000). An analysis along these lines has, however, been argued for by Byrne (1990) and Ouhalla (1999) for the structurally similar nominal clefts of Saramaccan and Arabic. Saramaccan has a focus structure (typified by sentence (9a)), which shares important properties with Coptic nominal clefts: the initial focus phrase precedes an open sentence (where the open position or gap is indicated as $e$ ). Moreover, a pronominal element may be 


\section{Chris H. Reintges, Anikó Lipták and Lisa Lai Shen Cheng}

inserted after the focus phrase, which copies its person and number feature. Byrne (1990) provides a single-clause analysis for that construction, in which the focused constituent (NP) is base-generated in an adjoined position to the $\mathrm{CP}$. According to this analysis, the optionally present pronoun represents a pronominal operator that has moved from the gap position, as schematically represented in (9b) (labels are from Byrne (1990).

(9) Saramaccan focus structures with optionally present pronouns

a. DÉÉ FÓ $\mathrm{U}_{\mathrm{i}}\left(\mathrm{DE}_{\mathrm{i}}\right)$ di wómi séi $e_{\mathrm{i}}$ a dí wójówójó the $(\mathrm{pl})$ bird THEY the man sell LOC the market

'The man sold the birds at the market.' (Byrne 1990: 67 (16a))

b. $\left[s \ldots N P_{i}\left[\mathrm{CPSPEC}\left(\mathrm{Y}_{\mathrm{i}}\right)\right.\right.$ Comp $\left.\left.\left(\mathrm{X}^{0}\right)\left[\mathrm{s} \ldots \mathrm{e}_{\mathrm{i}} \ldots\right]\right]\right]$

At first glance, a mono-clausal analysis of Coptic clefts seems to be supported, albeit indirectly, by the broad distribution of relativizing markers. As we can see from $(10 \mathrm{a}-\mathrm{d})$, the occurrence of relative markers like ontdoes not indicate relative embedding per se, since such markers appear not only in DP-internal relative clauses and clefts, but also in main clause whin-situ questions and declarative focus sentences.

(10) a. Relative clauses

e-pə-ma [CP ont-a-k-k ntə-f onhetə-f ]

to-DEF:SM-place REL-PERF-2SM-find-3SM inside-3SM

'to the place where you have found it (the boat)'

(Acts of Andrew and Paul 204: 145-146)

b. Wh-clefts

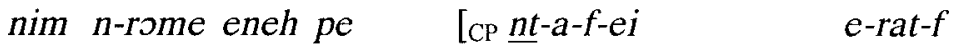

who of-man ever PRON:SM REL-PERF-3SM-come to-foot-3SM m-pe.n-jot e-f-mokh n-het

as-DEF:SM.1P-father REL(-PRES)-3SM-be.sad of-heart

e-me-f- $\beta$ ok e-f-rafe ] ?

REL-NEG.HAB-3SM-go REL(-PRES)-3SM-rejoice

'Which man ever (is there) that had gone to our father (Matthew) disheartened and did not go away rejoicing?' (KHML II 11:8-9)

c. Wh-in-situ questions

ont-a $u$ fope mmo-k pe.n-tfoeis po-rro?

REL-PERF what happen to-2SM DEF:SM.1P-lord DEF:SM-king

'What happened to you, our lord and king?'

(Eudoxia 36: 24) 
d. Focus-in-situ declaratives

ont-a-f-fiße gar an $n k^{y} i$ p-nute hon ne.f-hap
REL-PERF-3SM-change PCL NOT FM DEF:SM-god in DEF:P.3SM-law
'God has not changed in his laws. (Shenoute De Iudicio, 31:9-11)

In Reintges (2004a: ch. 4) and Reintges, LeSourd \& Chung (2005), the relative marking of the tense-aspect word is analysed as wh-agreement morphology, which flags classical wh-constructions (relative clauses, whquestions, and focusing constructions) and sets them apart from pragmatically neutral declaratives. Notice, however, that operator-variable constructions are not automatically flagged by special inflectional morphology: the relevant operator must also be in the appropriate configuration. As shown in (11a), relative marking is obligatory when the $w h$-phrase appears in-situ in a clause-internal argument or adverb position. By contrast, no such special inflection is resorted to when the $w h$-phrase appears ex-situ in a left-peripheral focus projection to the left of the perfect marker a-, as shown in (11b) below.

(11) a. Wh-in-situ question with relative marking

awo $\frac{n t-a-u-e r i}{\text { and }}$ REL-PERF-3P-come $\frac{\text { e } \beta O l}{\text { PCL }} \stackrel{\text { ton ? }}{\text { where }}$

'From where did they come?' (Apocalypse 7: 13, ed. Budge)

b. Wh-fronting question without relative marking

e $\beta O l$ ton a-teton-ei e-pei-ma?

PCL where PERF-2P-come to-DEM:SM-place

'From where did you come here?' (Budge, Martyrd. 220: 8)

Given the complementary distribution of $w h$-fronting and wh-agreement marking, the co-occurrence of the wh-phrase in Spec-FocusP and relative markers in $w h$-clefts like (10b) above would be somewhat mysterious under a mono-clausal analysis, but receives a straightforward explanation if $w h$ clefts involve minimally two clauses.

Further evidence for the biclausal structure of Coptic clefts comes from the limited distribution of the relative complementiser et-. This complementiser is licensed in subject relatives with present or future time reference, as $(12 \mathrm{a}-\mathrm{b})$ below illustrates. In such relative constructions, the relative complementiser must be adjacent to a gap (as opposed to a resumptive pronoun). In view of the fact that it is excluded from arguably mono-clausal $w h /$ focus-in-situ constructions, we can safely assume that the cleft predicate instantiates a relative clause proper. 
(12) a. Subject relative with et-complementiser

anok pe p-aggelos [CP et $\quad$ diakonei
I PRON:SM DEF:SM-angel C $\mathrm{C}_{\mathrm{REL}}$ (PRES) serve
e-pe.k-jot A $\quad$ Braham ]
to-DEF:SM.2SM-father Abraham
'I (am) the angel who serves your father Abraham'

(Testament of Issac 229: 19-20)

b. DP-clefts

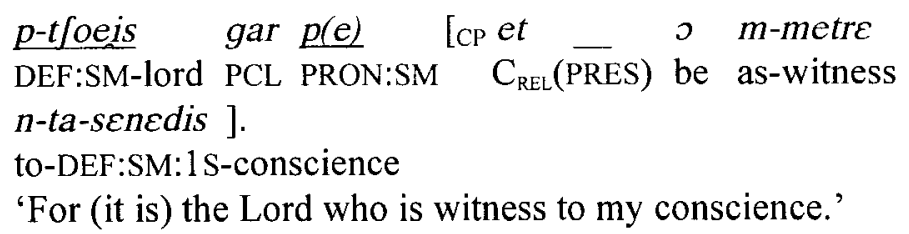

(V. Pach. 89: 1-2)

If the nominal cleft sentences with et-marked CP-predicates would be monoclausal structures, there would be nothing in the sentence that the gap would correspond to.

Ouhalla (1999) argues that the nominal cleft sentences in Modern Standard Arabic are simple equative copular sentence with the free relative functioning as the DP predicate: [F(OCUS)-XP PRON [DP RELATIVE CLAUSE]]. Compare (13a) with (13b), where the underlined string has the referential interpretation of a definite noun phrase (Ouhalla 1999: $343 \mathrm{ff}$.).

a. Nominal clefts in Modern Standard Arabic

ZAYNAB-u hiyya llatii Pallaf-at l-riwaayat-a

Zaynab-NOM PRON.she REL wrote-she the-novel-ACC

'It was ZAYNAB who wrote the novel.'

(Ouhalla 1999: $341(5 a)$ )

b. Free/headless relative clauses

wasal-a lladhi haddath-ta-nni an-hu arrived-he REL.the-he talked-you-to-me about-him 'The one you talked to me about has arrived.'

(Ouhalla 1999: 344 (6a))

In the Coptic counterpart, the predicate has no such DP layer, which would give it the syntactic distribution and referential properties of free relative clauses. In the examples considered so far, we have treated the deictic pronoun and the relative clause as independent sentence constituents. The very 
same surface string can also be found in free relative clauses, however. Compare pronominal pe in the cleft construction in (14a) with the formally identical definite article pe- 'the' that introduces the free relative clause pe-nt-a-i-meewe 'what I had thought' in (14b) below.

a. Pronoun cleft

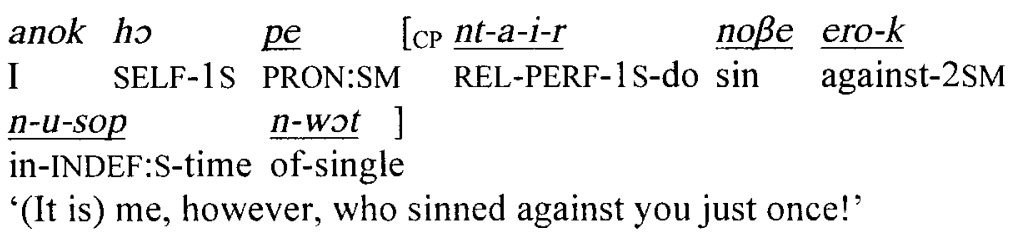

b. Free relative clauses

(Acts of Andrew and Paul 200: 87)

[DP pe-nt-a-i-meewe $\underline{\text { de }}$ ero-f ] a-i-aa-f

DEF:SM-REL-PERF-1S-think PCL about-3SM PERF-1S-do-3SM

'I did what I had thought about.'

(Budge, Martyrd. 207: 10)

If the nominal cleft construction consisted only of a DP and a free relative clause, we could not explain the following facts. First, in free relatives the prenominal definite article may vary with a freestanding demonstrative pronoun, as seen in $(15 \mathrm{a}-\mathrm{b})$. No such variation is attested for nominal cleft sentences. ([NP $\oslash]$ represents the empty nominal head of the free relative).

a. Free relative clauses with definite article $\mathrm{p}(\mathrm{e})-$

Judas p-apostolos $\left[_{\mathrm{DP}} p\right.$ - $\left[_{\mathrm{NP}} \emptyset\right] \mathrm{I}_{\mathrm{CP}}$ et _ moofe

Judas DEF:SM-apostle DEF:SM $\quad \mathrm{C}_{\text {REL }}$ (PRES) walk

mn pe.n-t foeis ]]

with DEF:SM.1P-lord

'the apostle Judas, who accompanied our Lord'

(Acts of Andrew and Paul 200: 74)

b. Free relative clauses with demonstrative pronoun pai
pe.n-jot Abraham I DP pai $I_{\mathrm{CP}} n t-\mathrm{a}-\mathrm{f}-\mathrm{mu}$
DEF:SM.1P-father Abraham DEM:SM REL-PERF-3:SM-die
'Our father Abraham, who had died'

Second, when free relative clauses occur in nominal predicational structures, the element pe shows up twice, namely as a determiner on the free relative clause and as a deictic pronoun linking the subject to the nominal predicate, see $(16 \mathrm{a}-\mathrm{b})$ below. No such repetition of pe is found in nominal cleft sentences, however. 
(16) Equative copular sentences with free relatives

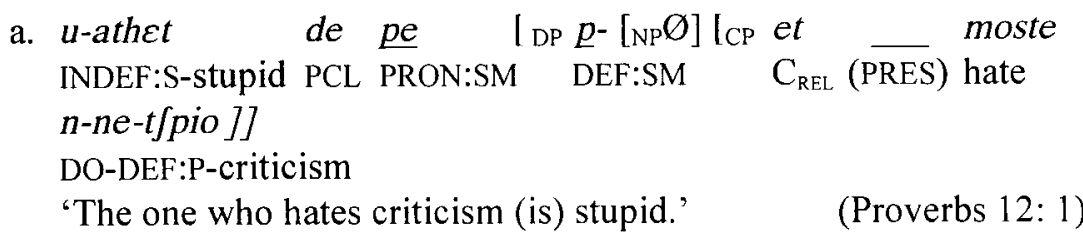

b. [DP ne- [NPØ] [CP nt-a-u-diakonei de kalos ]] $\underline{\text { ne }}$ DEF:P-REL-PERF-3P-serve PCL ADV PRON:P

[ $\mathrm{DP}$ ne- [NP $Ø]$ loP $n t-a-u-a h(e)$ e-rat-u

DEF:P-REL-PERF-3P-stand on-foot-3P

hm $p$-fi n-ne-graphe ]]

in DEF:SM-height of-DEF:P-scripture

'The ones who served well (are) the ones who stand within the confines of the Scriptures.' (Praec. et institut. Pach. 33: 30-31)

c. ntok pe [ you:SM PRON:SM DEF:SM $C_{\text {REL }}$ (PRES) come

'Are you the one who comes?'

(Luke 7:20)

Third, as we can see from (17a-b) below, the deictic pronoun may be dropped when the clefted constituent is an independent pronoun. By contrast, it is never possible for free relative clauses to omit the definite article or the demonstrative pronoun.

(17) Pronoun clefts with omission of the pronominal copula

a. anok [CP et_ na-kategori ommo-ton onahrom p-jot ] I $C_{\mathrm{REL}}$ FUT-accuse DO-2P before DEF:SM-father '(It is) I who will accuse you to the Father.'

(John 5: 45)

b. ntok [CP et_na-ti logos m-p-nute ha ta-psykhe] you:SM $C_{\text {REL }}$ FUT-give account to-DEF:SM-god for DEF:SF.1S-Soul '(It is) you who will account to God for my soul.'

(Hilaria 5: 28)

A final piece of evidence against a DP [DP FREE RELATIVE] analysis comes from the possibility of parenthetical expressions like vocative phrases to disrupt the syntactic continuity between the pronominal copula and the relative clause predicate. It is, however, never possible for vocatives to appear between the $\mathrm{D}^{0}$-head and the embedded relative clause. 
(18) COPULA > VOCATIVE $>$ RELATIVE CLAUSE

pe.k-fatfe pe pa-tfoeis [CP et _ tutfo

DEF:SM.2SM-word PRON:SM DEF:SM(-1s)-lord $C_{\text {REL }}$ (PRES) save

n-won nim ]

DO-one every

'(It is) your word, oh Lord, that saves everyone.' (Sapientia 10: 12)

In this section, we discussed and refuted a free relative clause analysis of the cleft predicate. The main argument concerns the systematic structural differences between nominal clefts and equative copular constructions.

\subsection{The categorial restriction on the clefted constituent}

Clefts in Coptic are more restricted than the English ones in that the clefted constituent cannot be of any other category than a DP. This categorial restriction is illustrated in the data in (19). Notice that Coptic has both argument (subject, direct, indirect and prepositional object) and adjunct clefts, but due to the categorial restriction it is never possible to cleft the entire prepositional or adverbial phrase, only the DP part of it:

ARGUMENT AND ADJUNCT CLEFTS

a. Subject

ta-feere $\frac{\text { tu-pistis }}{\mathrm{DEF}}$ te
DEF:SF(-1S)-daughter
[CP ont-a-s-nahme ]
REL-PERF-3SF-save(-2SF)
'My daughter, (it is) your faith that has saved you.'

(Luke 8: 48)

b. Direct Object

u-hok gar [CP e-nanu-f] pe

INDEF:S-thing PCL REL(-PRES)-be.fair-3sm PRON:SM

[CP $n t-a-f$-aa- $\underline{f}$ ]

REL-PERF-3SM-make-3SM

'(It is) a beautiful thing that he did.' (AP Chaîne no. 17, 3: 26) 
c. Prepositional object

u-mnt-at-noße t(e) [CP et-u-fine nso-s

INDEF:S-NOM-sinless PRON:SF $\quad \mathrm{C}_{\mathrm{REL}}$-PRES-3P-seek for-3SF

$n-$ toot-n ]

from-hand-1P

'(It is) a sinless (life) which is requested (lit. which they request)

from us.'

(Testament of Isaac 233:21)

d. Locative adverb

p-kah on pe [CP nt-a-ul-kto-un ero-f]

DEF:SM-earth PCL PRON:SM REL-PERF-3P-turn-3P to-3SM

'It (is) again the earth that they (i.e. the birds and the fish) turn themselves to.'

(Zenobius 202: 15-16)

e. Cause/reason adverb

awo nai n-tei-he $m n$ [DP ne- $[\mathrm{CP}$ et_eine

and DEM:P of-DEM:SM-kind with DEF:P- $\mathrm{C}_{\mathrm{REL}}$ (PRES) resemble mmo-u $]] n(\mathrm{e}) \quad[\mathrm{CP}$ etere p-fatje

DO-3P PRON:P REL(-PRES) DEF:SM-word

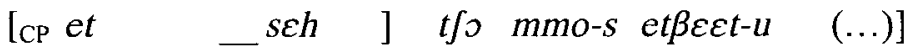

$\mathrm{C}_{\mathrm{REL}}$ (PRES) be.written say DO-3SF because.of-3P

'(It is) such kind of people and those who resemble them that the Scripture word (lit. the word that is written down) says about them $(\ldots)$

(Shenoute III 151:26-27)

In these examples the clefted constituent is always a DP, and it is linked either to a subject gap or a resumptive object pronoun inside the relative clause. We will relate this categorial restriction to the configuration we assign to nominal cleft sentences in section 4.1 .

\subsection{The agreement behaviour of the deictic copula}

The deictic pronoun agrees with the clefted DP in number and gender, but not in person. Consider the data in (20) below, all of which involve clefted DPs. 
(20) NP clefts with gender and number agreement of the pronominal copula

a. SINGULAR MASCULINE $p e$

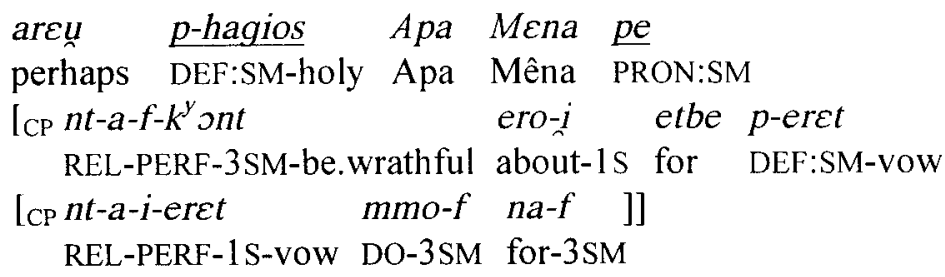

'Perhaps (it is) the holy Apa Mena who has become wrathful about me because of the vow that I made to him.'

(Mena, Mir. 11b: 25-29)

b. SINGULAR FEMININE te

te.k-hmhal Eudoxia t(e) [CP et - wof e-ei

DEF:SF.2SM-servant Eudoxia PRON:SF $C_{\text {REL }}$ (PRES) want to-go ehun e-pe. $k$-aspasmos ]

PCL to-DEF:SM-2SM-greeting

'(It is) your maid servant Eudoxia who wishes to enter to greet you.'

(Eudoxia 56: 1-2)

c. PLURAL ne

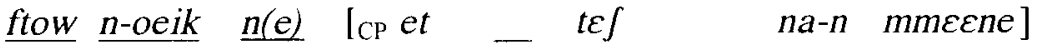
four of-bread PRON:P $C_{R E L}$ (PRES) be.portioned for-1P daily '(It is) four (loaves) of bread that are portioned to us daily.'

(Budge, Martyrd. 218: 25)

Clefted third person pronouns show the same agreement behavior as clefted DPs, as seen in (21):

(21) Third person pronouns clefts with gender and number agreement of the pronominal copula

a. SINGULAR MASCULINE $p e$

ne ntof mawaa-f pe [cP e-f-anakhorei

PRET HE alone-3SM PRON:SM REL(-PRES)-3SM-retreat

hm p-ma etmmau]

in DEF:SM-place that

'(It) was him alone who was living as a hermit in that place.'

(AP Chaîne no. 181, 43:21-22) 
b. PLURAL ne

[DP ne- [CP nt-a-u-mu mn pe-Khristos ]]

DEF:P REL-PERF-3P-die with DEF:SM-Christ

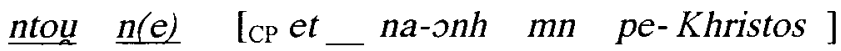

THEY PRON:P $C_{R E L}$ FUT-live with DEF:SM-Christ

'(As for) those who died with Christ, (it is) them who will also live with Christ.'

(Shenoute IV 4: 18-19)

The systematic absence of person agreement is evident in the context of clefted first and second person pronouns, where the deictic pronoun only reproduces the gender and number specification. This is why the third person pronouns $p(e)$ 'he' and $n(e)$ 'they' are selected in $(22 \mathrm{a}, \mathrm{b})$ rather than the clitic counterparts of the clefted pronominal. The unattested examples with full agreement between the clefted pronoun and the deictic copula are given in $\left(22 a^{\prime}, b^{\prime}\right)$. We take the non-occurrence of such examples to stem from a grammaticality restriction.

(22) First and second person pronoun clefts with gender and number, but not person agreement of the pronominal copula

a. SINGULAR MASCULINE pe

ontok p(e) [CP et

YOU(-SM) PRON:SM $C_{\text {REL }}$ (PRES) come

'(Is it) you who will come?'

(Luke 7: 20)

a.' *antok ontok [CP et _ neu ]

YOU(-SM) PRON:2SM C $C_{\text {REL }}$ (PRES) come

b. PLURAL ne

$\underline{\text { ontoton }} \underline{n(\mathrm{e})} \mathrm{I}_{\mathrm{CP}} \mathrm{et}$ - tmayo ommo-ton ]

YOU(-P) PRON:P $C_{\text {REL }}$ (PRES) justify DO-2P

'(It is) you that justify themselves.'

(Luke 16:15)

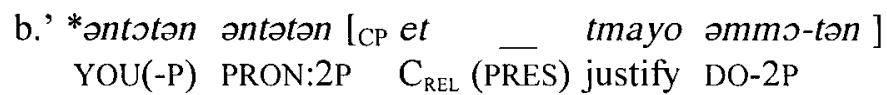

Furthermore, clefted personal pronouns may be construed with an invariant third person singular masculine pronominal $p e$, which gives rise to agreement mismatches of the following kind. 
(23) Pronoun clefts with invariant pe

a. ntos 'SHE' (Mismatch in gender)

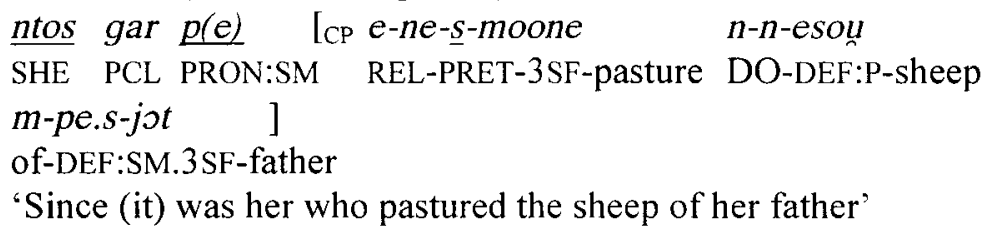

'Since (it) was her who pastured the sheep of her father'

(Genesis 29: 6)

b. anon 'WE' (Mismatch in number)

anon de mawaa-n p(e) [ $\mathrm{CP}_{\mathrm{CP}}$ et _ foop m-pei-ma]

WE PCL alone-1P PRON:SM $C_{\text {REL }}$ (PRES) be in-DEM:SM-place

'(It is) us alone who reside here.' (Budge, Martyrd. 221:2-3)

Finally, pronoun clefts allow for the deletion of the pronominal copula when the clefted pronoun is the antecedent of a subject relative clause. ${ }^{8}$

(24) Pronoun clefts with copula deletion

a. anok [cP et na-kategori əmmo-ton ənahrom p-jot ] I $C_{R E L}$ FUT-accuse DO-2P before DEF:SM-father '(It is) I who will accuse you to the father.'

(John 5: 45)

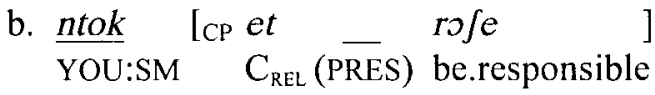

'(It is) you who is responsible.'

(Matthew 27: 4)

c. er-wof e-feene pu-tfai nsa $u$

REL-2SM-want to-give.away DEF:SM:2SF-boat for what

ntof $[\mathrm{CP}$ et _ saanf mmo ]

HE $\quad C_{\text {REL }}$ (PRES) keep.alive DO-2SF

'For what (purpose) do you (woman) wish to give away your boat? (It is) it (the boat) that keeps you alive!'

(KHML II 17: 1-3)

d. me ontoton an [CP et _ tso ommo-s (..)]

$Q$ YOU:P NOT $C_{\text {REL }}$ (PRES) say DO 3SF

'(It is) not you that say (...)'

(John 4: 35)

The main agreement patterns discussed so far are summarized in table 1. As evidenced by clefted first and second person pronouns, the deictic pronoun only express number and gender, but not person agreement with the clefted constituent. In other words, the absence of a morphological representation of grammatical person translates into a default third person form. 
Table 1. Subject agreement patterns in Sahidic nominal clefts

\begin{tabular}{llll}
\hline CLEFT & NUMBER AND GENDER & DEFAULT & COPULA \\
CONSTITUENT & AGREEMENT & AGREEMENT & DELETION \\
\hline DP & yes & no & no \\
$3^{\text {RD }}$ PRONOUNS & yes & yes & yes \\
$1^{\text {sT }} / 2^{\text {ND }}$ PRONOUNS & yes & yes & yes \\
\hline
\end{tabular}

The impoverishment of agreement can even be taken further as to assume an invariant third person singular masculine value, which leaves number and gender features unspecified. The deletion of the deictic pronoun represents the most radical case of featural underspecification.

\section{The configurational analysis of Coptic nominal clefts}

In this section, we present a configurational analysis that captures the interpretational and syntactic properties of nominal clefts in a straightforward way. We will argue that cleft formation in Coptic involves a two-step derivation, consisting of the merger of a small clause structure, and the subsequent $w h$-/focus-movement of its subject into a designated focus projection. We will also provide an explanation for the distribution of the gaps and resumptive pronouns in the relative clause predicate and its interaction with the alternations in the form of the relative complementiser.

\subsection{The small clause kernel}

As was shown in the previous section, Coptic nominal clefts instantiate a subject-predicate relationship, which is mediated by the deictic copula that links the clefted constituent and the relative clause. In structural terms, this means that the clefted element serves as subject to predication by the deictic pronoun + relative clause complex. Neither this complex, nor the relative clause itself is a free relative with a DP-layer. Given that the relative clause never occurs at the sentential level in other contexts beside clefting, we deduce that it by itself cannot function as a predicate. For the relative clause to assume such a predicative function, the deictic copula has to be introduced into the structure. Its role is that of spelling out the head of a 
small clause (SC) structure (see Stowell 1981; Moro 1997 on small clause structures in general, and Rothstein 1995; Doron 1986 on the role of pronominal copulas therein).

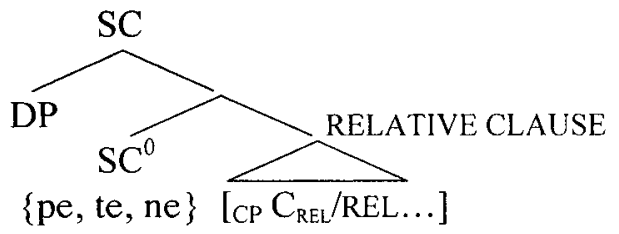

In Coptic, small clauses only license DP subjects, as the following examples of locative and nominal predicates illustrate.

a. Locative predication

ti-hem-pa-jot

1S-in-DEF:SM-1 s-father

'I am in my father.'

(John 14: 11)

b. Identificational nominal sentences (equatives)

anok pe p-fere m-p-nute

I PRON:SM DEF:SM-son of-DEF:SM-god 'I (am) the son of God.'

(Abbatôn 240: 13)

The categorial restriction on cleftability in Coptic to DPs can be directly related to the small clause structure in (25). In restricting cleft constituents to DPs, Coptic nominal clefts differ from their counterparts in more familiar languages like English and French, which allow for a much broader class of cleftable elements, including adverbial phrases and clausal complements (see, among various other, Huddleston \& Pullum 2002: 1417-1419 and Doetjes, Rebuschi \& Rialand 2004, but cf. Heggie 1993 for thematic and discourse restrictions on English clefts). We hypothesize that this typological variation reflects the fact that Coptic and English clefts are derived from different underlying structures, although they share the basic ingredients of this construction, viz. an initial focus constituent and a relative clause that contains the presupposition against which focusing takes place. 


\subsection{The left-peripheral position of the clefted DP}

Following É.Kiss's (1998) influential analysis, we present several arguments, based on the order of topics, complementisers and question particles, to show that the cleft constituent does not stay in the subject position of the small clause, but rather moves to the specifier position of a designated focus projection in the left periphery.

Consider first the data in $(27 a-b)$ below, which show that the clefted DP is not always the first element of the clause, but may be preceded by the finite 'THAT'-complementiser t $\int e$ and dedicated question particles like eye. We assume without further discussion that such clause-typing elements are merged into the $\mathrm{C}^{0}$-position. This indicates that the cleft constituent is not located in the operator position Spec, CP, but rather in the specifier of a lower functional projection.

COMP $>$ CLEFTED DP

a. Finite subordinating complementiser $\mathrm{t} \int \mathrm{e}$ eßol tse p-rro pe [cp nt-a-f-tamio-f na-s ]. PCL C DEF:SM-king PRON:SM REL-PERF-3SM-furnish-3SM for-3SF 'because (it was) the King who had furnished it (the chamber) for her.'

(Eudoxia 50: 8-9)

b. Q-PCL $>$ CLEFTED WH

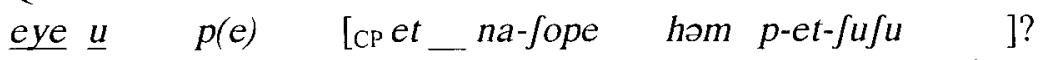

$\mathrm{Q}$ what? PRON:SM $\mathrm{C}_{\mathrm{REL}}$ FUT-happen to DEF:SM-C $\mathrm{C}_{\mathrm{REL}}$-dry

'What (is) it that will happen to the dried out one (the tree)?'

(Luke 23: 31)

In $(28 \mathrm{a}-\mathrm{b})$, we encounter topicalized constituents that precede the clefted DP. Their discourse status is indicated by the topicalizing particle de. This shows that the clefted DP is below higher topics. The clefted DP must therefore be located lower in the left periphery than discourse topics.

DISCOURSE TOPIC $>>$ CLEFTED DP

a. $\underline{\text { et } f n} \underline{n a i}$ de $\underline{u} \quad p(e) \quad[$ [сP ete-f-na-aa-f besides DEM:P PCL what PRON:SM REL-3SM-FUT-do-3SM $n k^{y} i$ p-diaßolos ] ?

FM DEF:SM-devil

'Besides these (things), what (is it) that the devil will (manage) to do?'

(Zenobius 203: 27-28) 
b. mmnsa p-hap de t-lote m-p-nun after DEF:SM-law PCL DEF:SF-pit of-DEF:SM-Abyss $t$ (e) [CP et na-fope na-k m-ma-m-moone ] PRON:SF $C_{R E L}$ FUT-become for-2SM as-dwelling.place 'But after the (day of) judgement, (it is) the pit of the Abyss that will become your dwelling place.'

(Eudoxia 38: 24-25)

However, as we can see in (29) below, topic phrases can also occur to the right of the clefted constituent. This lower topic position hosts various types of elements: left-dislocated personal pronouns (29a), emphatic reflexives (29b), topicalised time adverbials (29c).

CLEFTED WH $\gg$ LOWER TOPIC

$\begin{array}{llll}\text { a. } & \underline{u} \text { totn } & p(\mathrm{e}) \quad[\mathrm{CP} \text { ete-tn-we } \quad \text { tre-n-aa- } f \\ \text { what } & \text { YOU:P PRON:SM REL(-PRES)-2P-want CAUS:INF-1P-do-3SM }\end{array}$ nnahrn nai ]?

about DEM:P

'(As for) you, what (is it) that you want us to do about these (things)?'

(Cambyses 11:9-10)

b. $\underline{u} \underline{h o 0-n}$ on $p(e) \quad[\mathrm{CP}$ eto-n-na-aa-f]?

what self-1P PCL PRON:SM REL-1P-FUT-do-3SM

'What (is it) that we, on our part, shall do?'

(Luke 3: 14)

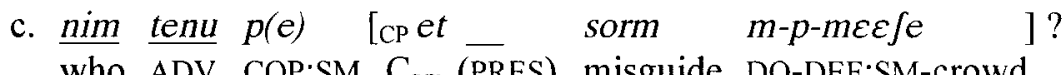

who ADV COP:SM $C_{\text {REL }}$ (PRES) misguide DO-DEF:SM-crowd

'Who (is it) now that is misleading the crowd?'

(Acts of Andrew and Paul 212: 231)

We thus propose that the left peripheral position of the cleft constituent is the result of $w h /$ focus-movement in the overt syntax. See diagram (30) for further illustration.

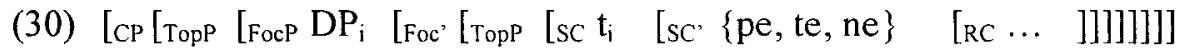

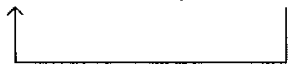

The proposed focus fronting process is cross-linguistically well attested as a general strategy in languages like Hungarian (É.Kiss 1987), Basque (Ortiz de Urbina 1989), Greek (Tsimpli 1995), and Hausa (Green \& Jaggar 2003). Focus fronting is also available as a marked alternative to in-situ focus in Coptic Egyptian (Reintges 2003, 2004a). ${ }^{9}$ 
4.3. The representation of the clefted constituent in the relative clause predicate

In this final section, we spell out how the cleft constituent is referentially linked to a gap or a resumptive pronoun in the associated relative clause. The broad syntactic distribution of resumptive pronouns in relative clauses is illustrated in (19b-e) above. Coptic resumptive pronouns behave differently from the ones found in English type languages in that they are not restricted to the context of island violations (see, among various others, Demirdache 1991; Tellier 1991; Shlonsky 1992)..$^{10}$

Following Demirdache $(1991,1997)$ we analyze resumptive pronominals as in-situ relative operators on a par with $w h$-in-situ phrases. The relative operator undergoes $w h$-movement to the specifier of $\mathrm{CP}$ thereby creating the relevant operator-variable dependency. On this view the resumptive pronoun represents the spell-out of the lower copy of the operator. The movement configuration of resumptive pronominalization is represented in diagram (31). See Browning (1997) for an early account of relative operators as null pronominals $\left(\mathrm{OP}_{\mathrm{PRON}}\right)$.

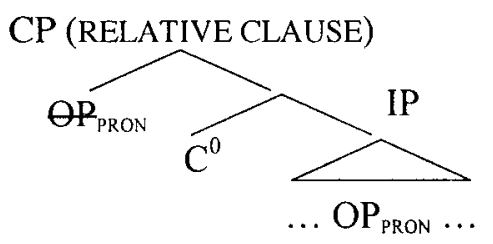

There is only one position where a gap appears instead of a resumptive pronoun, namely the highest subject position of the embedded clause (see Reintges 1998). The obligatory presence of a gap in this position has been attested in a variety of languages (see Borer 1984; McCloskey 1990; Demirdache 1997 for representative views on the "Highest Subject Restriction"). The presence of the gap in the subject position has a morphological correlate in the complementizer allomorph et-. In this case, we contend that the relative operator stays in-situ in the subject position. This raises the question about how the operator-variable dependency is created. We resort to a locality explanation along the lines of Agbayani (2000), who argues that the $w h$-subject of English questions is licensed in the Spec,TP position because it is locally adjacent to $\mathrm{C}^{0}$, the clause-typing head just as local as the Spec-CP position is. On this account, the operator binds a variable only after LF-raising. The configuration for Coptic subject relatives with an insitu relative operator would look like (32) below. 
(32)

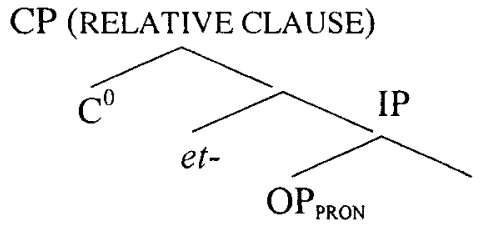

That locality is indeed the relevant licensing condition for the in-situ placement of the relative operator is evident from subject relative clauses in which intervening material disrupts the adjacency between the relative complementizer and the subject position. Consider the stacked relative clause in (33), where the possessive auxiliary verb wonta 'HAVE' appears sandwiched between the complementizer allomorph ete- and the embedded subject position. Notice that in this context a resumptive pronoun appears in the embedded subject position.

(33) Stacked relative clause with both subject gap and resumptive pronoun

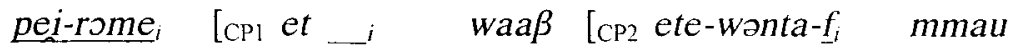
DEM:SM-man $C_{\text {REL }}$ (PRES) be.holy REL-HAVE-3SM there m-pei-mesfe n-arete l]

DO-DEM:SM-multitude of-virtue

'this holy man who possessed such a multitude of virtues'

(Budge, Hom. 2: 1-2)

A full analysis of the distribution of gaps and resumptive pronouns in Coptic relative constructions, which clearly depends on one's theory of locality, falls outside the scope of the present paper. We hope to tackle this issue in future research.

\section{Concluding remarks}

This paper dealt with the syntactic and semantic aspects of the nominal cleft construction in Coptic Egyptian. Nominal clefts in this language were shown to belong to a larger family of focusing constructions, where the fronted cleft constituent corresponds to contrastive (identificational) focus in the majority of cases, although non-contrastive, presentational focus readings are also available. As we have shown, Coptic clefts partake in the grammar of copular constructions. The deictic copula is merged into the 
head position of a small clause. It links the small clause subject, the clefted $\mathrm{NP}$, to its predicate, the associated relative clause. The clefted DP cannot remain in-situ in the subject position of the small clause, but has to undergo focus fronting to the specifier position of a designated focus phrase in the left periphery. The underlying small clause configurationality of Coptic nominal clefts provides a principled explanation for the categorial restriction on cleftable elements, which can only be DPs.

\section{Acknowledgements}

This paper has benefited from detailed comments by Marcel den Dikken, Barbara Egedi and an anonymous reviewer. The work of the first two authors was supported by the Netherlands Organisation for Scientific Research (NWO). All remaining errors are ours.

\section{Notes}

1. Since the Arab conquest of Egypt in $641 \mathrm{CE}$, Coptic was gradually replaced by Arabic for most practical purposes and reduced to a mainly ecclesiastical language, cultivated only by educated members of the Christian minority. The appearance of Coptic grammars, vocabularies, and textual editions written in Arabic in the $13^{\text {th }}$ century CE signal a revived interest in Coptic philology by Egyptian Christian scholars, but also the disappearance of Coptic as a spoken language.

2. Coptic Egyptian is the linguistic outcome of widespread bilingualism within a speech community, with Greek as the politically and culturally predominant language. Greek was not only the language of the literate elite, but also the language of the Holy Scriptures and the new religion and therefore a language of great cultural importance. Although no clear statistics are available at present, it is estimated that approximately forty percent of the Coptic vocabulary consists of Greek loan words. The transfer of Greek lexical material was not confined to lexical items, but also involved a considerable amount of function words, such as sentence conjunctions, discourse markers, manner and time adverbials, and even some prepositions. Language contact phenomena at all grammatical levels (lexicon, syntax, discourse structure) show that Coptic should be classified as a bilingual language variety with two parent languages, Egyptian and Greek (see Reintges 2004b for a more detailed discussion). 
3. The following abbreviations are used in the glosses. (Glosses are given in parentheses for morphemes that have no surface-segmental shape): 1 'first person'; 2 'second person'; 3 'third person'; ADV 'adverb', C 'subordinating complementiser'; $\mathrm{C}_{\text {REL }}$ 'relative complementiser'; CAUS.INF 'causative infinitive'; CONJ 'conjunctive'; DEF 'definite article', DEM 'demonstrative article'; DO 'direct object marker'; F 'feminine'; FM 'focus marker'; FUT 'future'; HAB 'habitual aspect'; INDEF 'indefinite article'; INF 'infinitive'; M 'masculine'; NEG 'negative scope marker'; NEG.PERF 'negative perfect'; NOM 'nominalising prefix'; PCL 'particle'; PERF 'perfect'; P 'plural'; PRES 'present tense'; PRET 'preterit'; PRON 'deictic pronoun/pronominal copula'; Q 'question particle'; REL 'relative marker'; $s$ 'singular'; TEMP 'temporal conjugation'. We distinguish relative markers from relative complementizers, since the former but not the latter can also appear in main clauses. See Reintges (2004a) for the text editions used in this article.

4. Note that the pronominal copula in nominal clefts is phonologically reduced (as indicated by the parentheses), but not in nominal sentences. This is because the deictic copula of clefts is a proclitic element that is attached phonologically to the adjacent relative clause, while its counterpart in equatives is a clausesecond enclitic. The phonological reduction of the deictic copula stems from an optional process of vowel elison (cf. $(2 \mathrm{a}, \mathrm{c})$ ): pe, te, ne $\rightarrow \mathrm{p}, \mathrm{t}, \mathrm{n} / \mathrm{C}_{\mathrm{RE:I}}$ et, ete, e, ere (cf. Polotsky 1962: 414 and Layton 2000: 371, §464).

5. As we can see from the grammaticality contrast between the (a) and the (b) examples of (i) and (ii), there is a definiteness restriction in the corresponding cleft constructions in Morrocan Arabic and Modern Hebrew.

(i) Definite restriction in Moroccan Arabic

a. L-WLAD huma lli sarrd-at (-hum) Nadia.

the-children PRON.they RM sent-she (-them) Nadia

'It was the CHILDREN that Nadia sent.' (Ouhalla 1999: 341 (5b))
b. ${ }^{*}$ WLAD huma lli sarrd-at (-hum) Nadia.
children PRON.they RM sent-she (-them) Nadia
*'It was CHILDREN that Nadia sent.'

(ii) Definite restriction in Modern Hebrew

a. Dani hu Se 'azar le Dina

Dani he that helped to Dina

'It is Dani who helped Dina.'

(Doron \& Heycock 1999: 77 (21))

b.??yeled hu Se 'azar le Dina

boy he that helped to Dina

'It is a boy/one boy who helped Dina.'

(Edit Doron, p.c.)

Ouhalla (1999: 341) hypothesizes that "the restrictive scope of the focus position in Arabic clefts may well have to do with the involvement of the pronominal copula", a plausible assumption given the mismatch in definiteness that would 
arise when an indefinite DP is clefted. Notice, however, that Coptic nominal clefts do not display any definiteness restrictions, yet employ the same type of pronominal copula to link the focus item to the cleft predicate.

6. In Coptic new information focus can be in-situ as shown by the question-answer pair in (i).

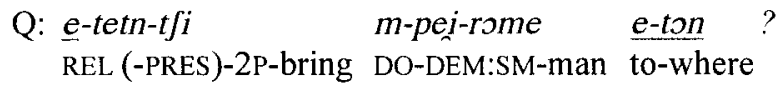
A: $\underline{e}-n-t f i$ mmo-f e-p-topos
$\underline{\text { n-Apa }} \quad \underline{\text { Mena }}$
REL (-PRES)-1P-bring DO-3SM to-DEF:SM-shrine of-Apa Mena

'Where do you bring this (sick) man to? - We bring him to THE SHRINE OF APA MENA'

(Mena, Mirc., 24b: 1-6)

Focus-in-situ constructions may also express explicit contrast, for instance, in the "NOT X BUT Y" construction, see (ii).
(ii) NEG: ompor pa-fere omp-u-tof-ək gar
no DEF:SM:1S-son NEG.PERF-3P-destine-2SM PCL
e-ti-oikonomia
for-DEM:SF-career
AFF: alla ont-a pa-tfoeis tof-ək e-u-solsol
but REL-PERF DEF:SM-lord destine-2SM for-INDEF:S-comfort
on-ne-sneu [CP et - waa $[\mathrm{CP}$ et - foop hom
for-DEF:P-brothers $\mathrm{C}_{\mathrm{RIII}}$ (PRES) be.holy $\mathrm{C}_{\mathrm{REL}}$ (PRES) live in
pə-tfaye ]]
DEF:SM-desert

'No, my son! For you have not been destined (lit. they have not destined you) FOR THIS CAREER (as a hermit), but the Lord has appointed you AS A COMFORT for the holy brothers who live in the desert'

(Budge, Martyrd 216: 33-217: 1)

The availability of identificational and new information focus fronting in insitu constructions has also been observed for Hausa (cf. Green \& Reintges 2004 for a comparative analysis).

7. In an earlier study, Koopman (1982) proposed a similar topicalisation analysis for Haitian cleft sentences, which was later refuted by Lumsden (1990) on the basis of the distribution of tense and negation. Naturally, a monoclausal analysis that involves adjunction of a focus constituent to $\mathrm{CP}$ would no longer be feasible in contemporary theory.

8. Coptic dialects display a considerable amount of variation with respect to copula deletion. The language variety represented by Papyrus Bodmer VI permits copula deletion not only in the context of clefted pronouns, but also in the contexts of clefted indefinites DPs, but only if the cleftee is not the subject of the embedded relative clause, as exemplified in (i) (see Polotsky 1962:425, fn. 1 for some discussion). 


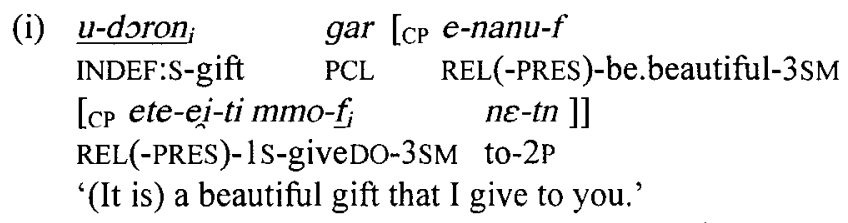

(Proverbs 4: 2 [Papyrus Bodmer VI])

Clearly, future research needs to clarify the parametric differences of Coptic language varieties with respect to copular agreement in nominal clefts.

9. In line with recent developments (Chomsky 2001), one could interpret this movement as being motivated by an unvalued operator feature on the attracting $\mathrm{Foc}^{0}$-head. When the cleftee is moved to the Spec, FocP position, the unvalued operator feature of $\mathrm{Foc}^{0}$ is valued, i.e. it is interpreted as [+identificational] or [+presentational] focus (see above, section 2 for the different semantic types of focus in Coptic clefts).

10. Naturally, Coptic resumptive pronouns will also occur as last resort devices in islands. This is illustrated by the following example, in which an entire cleft sentence is embedded inside a relative clause. The resumptive pronoun is found in the locative PP mmo-s 'in it' within the relative clause predicate, which is an island.

(i) Resumptive pronominalisation in Islands

$$
\begin{aligned}
& \text { u-poleis }_{i} \quad(. . .) I_{\mathrm{CP}} \text { e-hen-soßt } \quad \text { fem } n(\mathrm{e}) \\
& \text { INDEF:S-city REL(-PRES)-INDEF:P-wall small COP:P } \\
& \text { [CP et } \\
& \mathrm{C}_{\text {RII }} \text { (PRES) in-3SF } \\
& \text { 'a city (about which holds that) (it is) small walls that (there are) in it' }
\end{aligned}
$$

(Shenoute IV 24: 27)

\section{References}

Adger, David, Susan Pintzuk, Bernadette Plunkett and George Tsoulas (eds.)

1999 Specifiers: Minimalist approaches. New York: Oxford University Press.

Agbayani, Brian

$2000 W h$-subjects in English and the vacuous movement hypothesis. Linguistic Inquiry 31: 703-713.

Anagnostopoulou, Elena, Henk van Riemsdijk and Frans Zwarts (eds.)

1997 Materials on left-dislocation. Linguistik Aktuell / Linguistics Today 14. Amsterdam/Philadelphia: Benjamins.

Barbiers, Sjef, Johan Rooryck and Jeroen van de Weijer (eds.)

1998 Small words in the big picture: Squibs for Hans Bennis. HIL Occasional Papers 2, Leiden: Holland Institute of Generative Linguistics. 
Borer, Hagit

1984 Restrictive relatives in Modern Hebrew. Natural Language and Linguistic Theory 2: 219-260.

1986 The syntax of pronominal clitics. Syntax and Semantics 19: 313-332. Orlando: Academic Press.

Browning, Maggie

1987 Null operator constructions. Ph.D. dissertation, Massachusetts InstiByrne, Francis tute of Technology.

1990 Toward an account of preclausal focus in some Creole languages. Linguistics 28: 661-688.

Cheng, Lisa Lai-Shen and Norbert Corver (eds.)

2005 Wh-Movement moving on. Cambridge, Mass.: MIT Press.

Chomsky, Noam

2001 Derivation by phase. In Ken Hale: A life in language, M. Kenstowicz (ed.), 1-52. Cambridge, Mass.: MIT Press.

Demirdache, Hamida

1991 Resumptive chains in restrictive relatives, appositives and dislocation structures. Ph.D. dissertation, Massachusetts Institute of Technology.

1997 Dislocation, resumption and weakest crossover. In Materials on leftdislocation, Elena Anagnostopoulou, Henk van Riemsdijk and Frans Zwarts (eds.), 193-231. Linguistik Aktuell / Linguistics Today 14. Amsterdam/Philadelphia: Benjamins.

Doetjes, Jenny, Georges Rebuschi and Annie Rialand

2004 Cleft sentences. In Handbook of French semantics, Henriëtte de Swart and Francis Corblin (eds.). Stanford: CSLI.

Doron, Edit

1986 The pronominal copula as agreement clitic. In The syntax of pronominal clitics, Hagit Borer (ed.), 313-332. Syntax and Semantics 19. Orlando: Academic Press.

Doron, Edit and Caroline Heycock

1999 Filling and licensing multiple specifiers. In Specifiers: Minimalist approaches, David Adger, Susan Pintzuk, Bernadette Plunkett and George Tsoulas (eds.), 69-89. New York: Oxford University Press.

Green, Melanie and Philip Jaggar

2003 Ex-situ and in-situ focus in Hausa. In Research in Afroasiatic grammar $I I$, Papers from the fifth conference on Afroasiatic languages (Paris, June 2000), Jacqueline Lecarme (ed.), 189-214. Current Issues in Linguistic Theory 241. Amsterdam/Philadelphia: John Benjamins.

Green, Melanie and Chris H. Reintges

2004 Syntactic anchoring in Hausa and Coptic wh-constructions. In Papers of the Berkeley Linguistic Society, Special Session on Afro-Asiatic Languages, Andrew Simpson (ed.), 61-72. Berkeley: Linguistic Society. 
Heggie, Lorie

1993 The range of null operators. Natural Language and Linguistic Theory 11: 45-84.

Huddleston, Rodney and Geoffrey K. Pullum

2002 The Cambridge grammar of the English language. Cambridge: Cambridge University Press.

Kenstowicz, Michael (ed.)

2001 Ken Hale: A life in language. Current Studies in Linguistics 36.

Kiss, Katalin É.

Cambridge, Mass.: The MIT Press.

1987 Configurationality in Hungarian. Budapest: Akadémiai Kiadó.

1998 Identificational focus versus information focus. Language 74: 245273.

Kiss, Katalin É. (ed.)

1995 Discourse configurational languages. New York: Oxford University Press.

Koopman, Hilda

1982 Les questions. In Syntaxe de l'Haitien, Claire Lefebvre, Hélène Magloire-Holly and Nannie Piou (eds.). Ann Arbor, Michigan: Karoma.

Lambrecht, Knud

2001 A framework for the analysis of cleft constructions. Linguistics 39: $463-516$.

Layton, Bentley

2000 A Coptic grammar with chrestomathy and glossary. Porta Linguarum Orientalium N.S. 20. Wiesbaden: Harrassowitz.

Lecarme, Jacqueline (ed.)

2003 Research in Afroasiatic grammar II. Papers from the fifth conference on Afroasiatic languages (Paris, June 2000). Current Issues in Linguistic Theory 241. Amsterdam/Philadelphia: John Benjamins.

Lefebvre, Claire, Hélène Magloire-Holly and Nannie Piou (eds.)

1982 Syntaxe de l'Haitien. Ann Arbor, Michigan: Karoma.

Lumsden, John S.

1990 The biclausal structure of Haitian clefts. Linguistics 28: 741-759.

McCloskey, Jim

1990 Resumptive pronouns, A'-Binding, and levels of representation in Irish. Syntax and Semantics 23.

Moro, Andrea

1997 The raising of predicates: Predicative noun phrases and the theory of clause structure. Cambridge: Cambridge University Press.

Ortiz de Urbina, Jon

1989 Parameters in the grammar of Basque. Dordrecht: Foris. 
Ouhalla, Jamal

1999 Focus and Arabic clefts. In The grammar of focus, Georges Rebuschi and Lauri Tuller (eds.), 335-359. Amsterdam/Philadelphia: Benjamins.

Polotsky, Hans Jacob

1962 Nominalsatz und Cleft Sentence im Koptischen. Orientalia 31: 413430 .

Rebuschi, Georges and Laurie Tuller (eds.),

1999 The grammar of focus. Amsterdam/Philadelphia: Benjamins.

Reintges, Chris $\mathrm{H}$.

1998 The 'Highest Subject Restriction' in Coptic relative clauses. In Small words in the big picture: Squibs for Hans Bennis, Sjef Barbiers, Johan Rooryck, and Jeroen van de Weijer (eds), 83-89. HIL Occasional Papers 2, Leiden: Holland Institute of Generative Linguistics.

2003 Syntactic conditions on special inflection in Coptic interrogatives. In Research in Afroasiatic grammar II, Papers from the fifth conference on Afroasiatic languages (Paris, June 2000), Jacqueline Lecarme (ed.), 363-408. Amsterdam/Philadelphia: John Benjamins.

2004a Coptic Egyptian (Sahidic dialect): A learner's grammar. Afrikawissenschaftliche Lehrbücher 15. Cologne: Rüdiger Köppe Verlag.

2004b Coptic Egyptian as a bilingual language variety. In Lenguas en contacto de la Antigüedad a la Edad Media [Languages in contact in Antiquity and the Middle Ages], S. Torallas Tovar (ed.). Madrid: Consejo Superior de Investigaciones Cientificas.

Reintges, Chris H., Philip LeSourd and Sandra Chung

2005 Movement, Wh-Agreement, and apparent $W h$-in-situ. In Wh-Movement moving on, Lisa Lai Shen Cheng and Norbert Corver (eds.). Cambridge, Mass.: MIT Press.

Rooth, Mats

1992 A theory of focus interpretation. Natural Language Semantics 1: 75 116.

Rothstein, Susan

1995 Small clauses and copular constructions. Syntax and semantics 28: Small clauses, 27-48. New York: Academic Press.

Shlonsky, Ur

1992 Resumptive pronouns as a last resort. Linguistic Inquiry 23: 443-468. Simpson, Andrew (ed.)

2004 Proceedings of the twenty-seventh annual meeting of the Berkeley Linguistics Society, March 22-25, 2001, Special Session on Afroasiatic Languages. Berkeley: Linguistic Society.

Stowell, Tim

1981 Origins of phrase structure. Ph.D. dissertation. Massachusetts Institute of Technology. 
de Swart, Henriëtte and Francis Corblin (eds.)

forthc. Handbook of French semantics. Stanford: CSLI.

Tellier, Christine

1991 Licensing theory and French parasitic gaps. Dordrecht: Kluwer Academic Publishers.

Torallas Tovar, S. (ed.)

2004 Lenguas en contacto de la Antigüedad a la Edad Media (Languages in contact in Antiquity and the Middle Ages). Madrid: Consejo Superior de Investigaciones Cientificas.

Tsimpli, I. M

1995 Focusing in Modern Greek. In Discourse configurational languages, Katalin É. Kiss (ed.), 176-206. New York: Oxford University Press. 